\title{
Enhanced Ammonia Synthesis Activity of Ceria-Supported Ruthenium Catalysts Induced by CO Activation
}

\author{
Bingyu Lin ${ }^{1}$, Biyun Fang ${ }^{1}$, Yuyuan $\mathrm{Wu}^{1}$, Chunyan $\mathrm{Li}^{1}$, Jun $\mathrm{Ni}^{1}$, Xiuyun Wang ${ }^{1}$, Jianxin \\ $\mathrm{Lin}^{1}$, Chak-tong $\mathrm{Au}^{1}$, and Lilong Jiang ${ }^{2}$ \\ ${ }^{1}$ National Engineering Research Center of Chemical Fertilizer Catalyst \\ ${ }^{2}$ Fuzhou University
}

September 28, 2020

\begin{abstract}
Metal-support interactions strongly affect the catalytic performances of ceria-supported metal catalysts, and hydrogen treatment at high temperature is important for the preparation of catalysts that show strong metal-support interaction (SMSI). With SMSI, the proportion of metal species existed in the form of metallic state is lowered, consequently hindering the performance of a metal catalyst for a reaction that requires metallic sites. Here we show that $\mathrm{CO}$ activation of a $\mathrm{Ru} / \mathrm{CeO} 2$ catalyst not only enhances the reduction degree and exposure of Ru species, but also increases Ce3+ concentration, oxygen vacancy (OV) and active oxygen, resulting in the formation of electron-enriched Ruó- species and Ruó--OV-Ce3+ sites. As a result, a Ru/CeO2 catalyst after $\mathrm{CO}$ activation shows high ammonia synthesis activity, and the ill effect of hydrogen poisoning is effectively alleviated. These findings are important for the design of supported metal catalysts that afford metallic species as active sites.

\section{Enhanced Ammonia Synthesis Activity of Ceria-Supported Ruthenium Catalysts Induced by} CO Activation

Bingyu Lin*, Biyun Fang, Yuyuan Wu, Chunyan Li, Jun Ni, Xiuyun Wang, Jianxin Lin, Chak-tong Au, Lilong Jiang*

National Engineering Research Center of Chemical Fertilizer Catalyst, College of Chemical Engineering, Fuzhou University, Fuzhou 350002, Fujian, China

E-mail: bylin@fzu.edu.cn (Bingyu Lin); jll@fzu.edu.cn (Lilong Jiang); Fax: +86 0591-83738808; Tel: +86 0591-83731234

Abstract: Metal-support interactions strongly affect the catalytic performances of ceria-supported metal catalysts, and hydrogen treatment at high temperature is important for the preparation of catalysts that show strong metal-support interaction (SMSI). With SMSI, the proportion of metal species existed in the form of metallic state is lowered, consequently hindering the performance of a metal catalyst for a reaction that requires metallic sites. Here we show that $\mathrm{CO}$ activation of a $\mathrm{Ru} / \mathrm{CeO}_{2}$ catalyst not only enhances the reduction degree and exposure of $\mathrm{Ru}$ species, but also increases $\mathrm{Ce}^{3+}$ concentration, oxygen vacancy $\left(\mathrm{O}_{\mathrm{V}}\right)$ and active oxygen, resulting in the formation of electron-enriched $\mathrm{Ru}^{\delta-}$ species and $\mathrm{Ru}^{\delta-}-\mathrm{O}_{\mathrm{V}}-\mathrm{Ce}^{3+}$ sites. As a result, a $\mathrm{Ru} / \mathrm{CeO}_{2}$ catalyst after $\mathrm{CO}$ activation shows high ammonia synthesis activity, and the ill effect of hydrogen poisoning is effectively alleviated. These findings are important for the design of supported metal catalysts that afford metallic species as active sites.
\end{abstract}

Keywords: Ammonia synthesis, $\mathrm{CO}$ activation, Metal-support interaction, $\mathrm{Ru} / \mathrm{CeO}_{2}$

\section{Introduction}


Ammonia $\left(\mathrm{NH}_{3}\right)$ is not only an important chemical for the synthesis of N-containing compounds, ${ }^{1}$ but also a carrier of hydrogen energy. ${ }^{2-3}$ The process of catalytic ammonia synthesis from hydrogen and nitrogen consumed $1-2 \%$ of the world's energy every year; ${ }^{4-6}$ thus it is urgent to develop an efficient catalyst and sustainable process for ammonia production. Recently, ceria-supported Ru catalysts have attracted much interest in ammonia synthesis due to the unique electronic property, $\mathrm{Ce}^{4+} / \mathrm{Ce}^{3+}$ redox ability and hydrogen adsorption capacity of ceria. ${ }^{7-11}$

In general, the interaction between reducible oxides and metal species has a strong effect on catalytic performance. ${ }^{12-14}$ Strong metal-support interaction (SMSI), electronic metal-support interaction (EMSI), and nature of interfacial perimeter are known factors that would cause such an effect. SMSI is due to the coverage of metal particles by suboxides, which could enhance catalytic activities by inducing Lewis acidity and/or changing the electronic structure of metal species. ${ }^{15-19}$ Furthermore, as a result of charge transfer or EMSI between metal species and reducible oxide support, there is electronic perturbation and electron rearrangement of metal species, leading to enhancement of catalytic performance as a result of changes in adsorption and/or dissociation properties of reactant gases. ${ }^{12,}{ }^{20-21}$ On the other hand, the accumulation of excess charges or close contact between support and metal species at the interfacial perimeter sites would affect the adsorption, desorption, reaction and spillover of reactants or products, consequently exerting a strong influence on the activities of oxides-supported metal catalysts. ${ }^{22-25}$

Ammonia synthesis consists of several reaction steps, including the adsorption and dissociation of $\mathrm{N}_{2}$ and $\mathrm{H}_{2}$ molecules, the reaction of $\mathrm{N}$ and $\mathrm{H}$ atoms, and the desorption of unreacted gases $\left(\mathrm{N}_{2}\right.$ and $\left.\mathrm{H}_{2}\right)$ and $\mathrm{NH}_{\mathrm{x}}$ species. ${ }^{26-27}$ It is envisioned that any change in Ru-ceria interaction of a $\mathrm{Ru} /$ ceria catalyst would strongly affect the catalytic activity for ammonia synthesis due to alteration of adsorption properties of reactant gases. Through the decrease of metal loading, one can enhance metal-support interaction and increase atom economy by maximizing the number of interfacial sites. Guo et al. observed that SMSI was the strongest for $\mathrm{Ru} / \mathrm{CeO}_{2}$ with single $\mathrm{Ru}$ atoms, and hydrogen spillover was more pronounced for catalyst samples with larger $\mathrm{Ru}$ particles. Moreover, $\mathrm{Ru}$ in the form of $\mathrm{Ru}$ clusters showed high activities in $\mathrm{CO}_{2}$ methanation because there was a balance between SMSI and H-spillover effect. ${ }^{28}$ Ganzler et al. proposed that large Pt particles lowered the reducibility of ceria, and the activity for CO oxidation decreased as a result of the decrease of interfacial sites between ceria and Pt particles. ${ }^{29}$ Lykhach et al. showed that the charge transfer between Pt species and ceria was governed by the size of Pt particles. ${ }^{14}$ It was observed that a higher reduction temperature is required for the preparation of a catalyst with SMSI, especially for catalysts with metal clusters of small size. ${ }^{30-31}$ Unfortunately, there was sintering of metal clusters during high temperature reduction, ${ }^{31}$ and the decoration or encapsulation of metal species by suboxides from the reducible support would lower the proportion of metal species that exist in metallic state. The detrimental effect of the diminution of metallic sites on catalytic performance would be pronounced for catalytic reactions that require metallic species as active sites, such as the reactions for ammonia synthesis.

In the present work, we demonstrate that for $\mathrm{Ru} / \mathrm{CeO}_{2}$ catalyst the reduction degree and the exposed proportion of $\mathrm{Ru}$ species could be enhanced by $\mathrm{CO}$ activation, leading to significant enhancement of $\mathrm{Ce}^{3+}$, oxygen vacancy $\left(\mathrm{O}_{\mathrm{V}}\right)$ and active oxygen concentration that are beneficial for the formation of electron-enriched $\mathrm{Ru}^{\mathrm{\delta}-}$ species, $\mathrm{Ru}^{\delta-}-\mathrm{O}_{V^{-}}-\mathrm{Ce}^{3+}$ sites and surface active oxygen. As a result, there is significant change of hydrogen adsorption property, and the $\mathrm{Ru} / \mathrm{CeO}_{2}$ catalyst after $\mathrm{CO}$ activation shows higher ammonia synthesis activity, with the ill effect of hydrogen poisoning significantly alleviated.

\section{Experimental Section}

\subsection{Catalyst Preparation}

$\mathrm{CeO}_{2}$ was prepared according to the process described elsewhere. ${ }^{10,32}$ The $\mathrm{RuNO}_{3} / \mathrm{CeO}_{2}$ was obtained by incipient wetness impregnation of ceria with ruthenium(III) nitrosyl nitrate solution $(1.5 \% \mathrm{w} / \mathrm{v}$, Aldrich), and the nominal $\mathrm{Ru}$-to-ceria weight ratio was $1 \%$. A portion of the obtained $\mathrm{RuNO}_{3} / \mathrm{CeO}_{2}$ was reduced in hydrogen at $550{ }^{\circ} \mathrm{C}$ for $6 \mathrm{~h}$ and is herein denoted as $\mathrm{Ru} / \mathrm{CeO}_{2}-\mathrm{H}$. The rest of $\mathrm{RuNO}_{3} / \mathrm{CeO}_{2}$ was treated in $\mathrm{CO}$ gas at 250 or $500{ }^{\circ} \mathrm{C}$ for $2 \mathrm{~h}$ to obtain $\mathrm{Ru} / \mathrm{CeO}_{2}-\mathrm{Cx}$, where $x$ is the $\mathrm{CO}$ treatment temperature. 
Afterwards, $\mathrm{Ru} / \mathrm{CeO}_{2}-\mathrm{C} x$ was reduced in hydrogen at $550{ }^{\circ} \mathrm{C}$ for $6 \mathrm{~h}$, and the as-obtained catalysts are denoted as $\mathrm{Ru} / \mathrm{CeO}_{2}-\mathrm{C} x \mathrm{H}$.

\subsection{Catalyst Characterization}

D/H exchange reaction was conducted on a Micromeritics AutoChem II 2920 equipment. First, $100 \mathrm{mg}$ of a sample was treated at $550{ }^{\circ} \mathrm{C}$ for $6 \mathrm{~h}$ in hydrogen, then purged with $\mathrm{Ar}$ and cooled down to $400{ }^{\circ} \mathrm{C}$. Afterwards, the sample was exposed to $\mathrm{D}_{2}$ and held at $400{ }^{\circ} \mathrm{C}$ for $1 \mathrm{~h}$. After cooling to $50{ }^{\circ} \mathrm{C}$ in $\mathrm{D}_{2}$ and purged with $\mathrm{Ar}$ for $1 \mathrm{~h}$, the sample was exposed to a $3.3 \% \mathrm{~N}_{2}-10 \% \mathrm{H}_{2}$-Ar mixture, and the mass signals were recorded by a Hiden Analytical HPR-20 spectrometer.

Temperature-programmed surface reaction (TPSR) measurement was carried out on the same AutoChem II 2920 instrument. The fresh sample was exposed to $\mathrm{D}_{2}$, $\mathrm{Ar}$, or $\mathrm{N}_{2}$ at $400 \operatorname{deg} \mathrm{C}$ for $1 \mathrm{~h}$, and then cooled to 50 $\operatorname{deg} \mathrm{C}$ in the gas selected for exposure. Finally, the feed gas was switched to a $3.3 \% \mathrm{~N}_{2}-10 \% \mathrm{H}_{2}-\mathrm{Ar}$ mixture, and the catalyst sample was heated to $600 \operatorname{degC}$.

Other characterizations including $\mathrm{N}_{2}$ physisorption, X-ray diffraction (XRD), transmission electron microscopy (TEM), Raman, diffuse reflectance infrared Fourier transform spectroscopy (DRIFTS), hydrogen temperature-programmed reduction $\left(\mathrm{H}_{2}-\mathrm{TPR}\right)$, X-ray phototoelectron spectroscopy (XPS), $\mathrm{H}_{2}$ chemisorption, are given in Supporting Information.

\subsection{Catalyst Evaluation}

Ammonia synthesis was carried out in a continuous flow fixed-bed stainless steel reactor (inner diameter $=$ $12 \mathrm{~mm})$. Prior to reaction, the catalyst $(0.20 \mathrm{~g}, 32-60$ mesh) was diluted with quartz sand of similar size and reduced in a stoichiometric $\mathrm{H}_{2}-\mathrm{N}_{2}$ gas mixture at $550 \operatorname{deg} \mathrm{C}$ for $6 \mathrm{~h}$. There were no external and internal diffusion limitations under the conditions adopted in this work. ${ }^{33-34}$ Catalyst evaluation was conducted after the reaction was maintained for more than $3 \mathrm{~h}$ under a selected condition. The produced ammonia was trapped by sulfuric acid solution and then analyzed by ion chromatography (Thermo Scientific, ICS-600); subsequently, the reaction rates and TOF values could be obtained.

\section{Results and Discussion}

\subsection{Structure Characterization}

The BET areas of prepared Ru catalysts are in the range of $81-86 \mathrm{~m}^{2} \mathrm{~g}^{-1}$ (Table S1), indicating that the adopted treatment conditions have only a slight effect on the specific surface area of Ru catalysts. XRD patterns of cubic fluorite $\mathrm{CeO}_{2}$ phase (JCPDS 34-0394) can be observed for all samples (Figure S1), suggesting that the treatments do not alter the crystal phase of ceria support. There is no detection of diffraction peaks ascribable to $\mathrm{Ru}$ species, indicating well dispersion of $\mathrm{Ru}$ species on ceria, which is in consistent with the aberration-corrected HAADF-STEM images (Figure S2). The as-prepared $\mathrm{RuNO}_{3} / \mathrm{CeO}_{2}$ catalyst shows two $\mathrm{Ru} 3 \mathrm{~d}_{5 / 2}$ peaks at $281.4 \mathrm{eV}$ and $282.8 \mathrm{eV}$ that are characteristic of $\mathrm{Ru}^{4+}$ and $\mathrm{Ru}^{6+}$, respectively (Figure S3). ${ }^{10}, 35-38$ Strong hydrogen reduction peak at $128 \mathrm{degC}$ and a weak shoulder peak at $200 \mathrm{degC}$ in the $\mathrm{H}_{2}$ - TPR profile of $\mathrm{RuNO}_{3} / \mathrm{CeO}_{2}$ can be assigned to the reduction of $\mathrm{RuO}_{\mathrm{x}}$ and $\mathrm{CeO}_{2}$, respectively (Figure S4). However, only a broad and weak hydrogen consumption peak in the temperature range of 70 to $400 \mathrm{deg} \mathrm{C}$ can be observed over the $\mathrm{Ru} / \mathrm{CeO}_{2}-\mathrm{C} 250$ and $\mathrm{Ru} / \mathrm{CeO}_{2}-\mathrm{C} 500$ catalysts, indicating that most of the $\mathrm{Ru}$ species has been reduced during $\mathrm{CO}$ activation.

The distinct bands corresponding to reduced $\mathrm{Ru}^{0}$ species can be observed in the DRIFTS spectra taken over $\mathrm{RuNO}_{3} / \mathrm{CeO}_{2}$ exposed to $\mathrm{CO}$ at $150 \mathrm{degC}$ (Figure S5), indicating that $\mathrm{Ru}$ oxides on the ceria surface can be activated by $\mathrm{CO}$ at $150 \mathrm{deg}$. A further increase of activation temperature would lead to the dissociation of $\mathrm{CO}$ molecules on the $\mathrm{Ru}$ surface, and the produced oxygen could oxidize metallic Ru species and spillover to ceria, a phenomenon similar to that observed over ceria-supported Co catalyst as reported by Parastaev et al. ${ }^{31}$ As a result, the presence of ruthenium oxide can be detected in the DRIFTS (Figure S5) or XPS investigations of $\mathrm{Ru} / \mathrm{CeO}_{2}$-C500 (Figure S6). There are three distinct $\mathrm{CO}$ bands at 1985, 2063 and 2125 $\mathrm{cm}^{-1}$ in the DRIFTS spectra of the $\mathrm{Ru} / \mathrm{CeO}_{2}-\mathrm{H}, \mathrm{Ru} / \mathrm{CeO}_{2}-\mathrm{C} 250 \mathrm{H}$ and $\mathrm{Ru} / \mathrm{CeO}_{2}-\mathrm{C} 500 \mathrm{H}$ catalysts (Figure 
S7), which are assignable to bridge-type $\mathrm{CO}$ species bonded to Ru metal, linearly adsorbed $\mathrm{CO}$ species on reduced $\mathrm{Ru}$ particles, and carbonyl species on partially oxidized $\mathrm{Ru}\left(\mathrm{Ru}^{n+}\right)$, respectively, ${ }^{37,} 39-40$ indicating the coexistence of ruthenium oxide and ruthenium metal for all samples.

Presented in Figures 1a-c are the XPS Ce 3d, Ru 3d and O 1s spectra of the as-prepared ceria-supported $\mathrm{Ru}$ catalysts. The $\mathrm{Ce} 3 \mathrm{~d}$ profiles can be deconvoluted into ten peaks, two pairs of $3 \mathrm{~d}_{5 / 2}(880.4 \mathrm{eV}$ and $884.8 \mathrm{eV}$ ) and their $3 \mathrm{~d}_{3 / 2}$ features are assigned to $\mathrm{Ce}^{3+}$ species, and the other six Ce $3 \mathrm{~d}$ peaks are ascribed to $\mathrm{Ce}^{4+}$ species. The $\mathrm{O} 1 \mathrm{~s}$ spectra can be deconvoluted into two peaks at $529.0 \mathrm{eV}$ and $531.2 \mathrm{eV}$, which are characteristic of lattice oxygen and oxygen vacancies $\left(\mathrm{O}_{\mathrm{V}}\right)$, respectively. ${ }^{35-36,41}$ Compared to the use of $\mathrm{H}_{2}$ as reducing agent, the use of $\mathrm{CO}$ can lead to pronounced ceria reducibility of ceria-supported metal catalysts. ${ }^{29,42}$ Thus the $\mathrm{Ce}^{3+}$ and $\mathrm{O}_{\mathrm{V}}$ concentrations of the $\mathrm{CO}$ activated samples, as evaluated by the ratios of $\mathrm{Ce}^{3+} /\left(\mathrm{Ce}^{3+}+\mathrm{Ce}^{4+}\right)$ and $\mathrm{O}_{\beta} / \mathrm{O}_{\alpha},{ }^{35,41}$ are higher than those of $\mathrm{Ru} / \mathrm{CeO}_{2}-\mathrm{H}$ (Figure 1d).

Figure 1 XPS spectra of as-prepared $\mathrm{Ru}$ catalysts (a) $\mathrm{Ce} 3 \mathrm{~d}$, (b) $\mathrm{Ru} 3 \mathrm{~d}$, and (c) $\mathrm{O}$ 1s; (d) $\mathrm{Ce}^{3+} /\left(\mathrm{Ce}^{3+}+\mathrm{Ce}^{4+}\right), \mathrm{O}_{\beta} / \mathrm{O}_{\alpha}$ and $\left(\mathrm{Ru}^{0}+\mathrm{Ru}^{\delta-}\right) /\left(\mathrm{Ru}^{0}+\mathrm{Ru}^{\mathrm{\delta}}+\mathrm{Ru}^{\mathrm{n}+}\right)$ intensity ratios.

Besides the $\mathrm{Ru} 3 \mathrm{~d}_{5 / 2}$ peaks of ruthenium oxides $\left(\mathrm{Ru}^{4+}\right.$ and $\left.\mathrm{Ru}^{6+}\right)$, there is a new $\mathrm{Ru} 3 \mathrm{~d}_{5 / 2}$ peak at 279.8 $\mathrm{eV}$ for the $\mathrm{Ru} / \mathrm{CeO}_{2}-\mathrm{H}, \mathrm{Ru} / \mathrm{CeO}_{2}-\mathrm{C} 250 \mathrm{H}$ and $\mathrm{Ru} / \mathrm{CeO}_{2}-\mathrm{C} 500 \mathrm{H}$ catalysts (Figure $1 \mathrm{~b}$ ), which is characteristic of metallic $\mathrm{Ru}^{0}{ }^{10}{ }^{135-38}$ Because some $\mathrm{Ru}$ species is covered by suboxides originated form ceria, the $\mathrm{Ru}^{0} /\left(\mathrm{Ru}^{0}+\mathrm{Ru}^{\mathrm{n}+}\right)$ ratio of $\mathrm{Ru} / \mathrm{CeO}_{2}-\mathrm{H}$ is much smaller, only11.7\%, which can be related to SMSI. During hydrogen treatment of ceria-supported $\mathrm{Ru}$ catalysts, reverse oxygen spillover from ceria to ruthenium oxides leads to the formation of oxygen vacancies as well as the encapsulation of $\mathrm{Ru}$ metal by suboxides (Figure S8). ${ }^{31,43-44}$ As a result, the proportion of exposed $\mathrm{Ru}$ species would decrease, and the $\mathrm{Ru} 3 \mathrm{~d}$ to Ce 3d intensity ratio $\left(\mathrm{I}_{\mathrm{Ru} 3 \mathrm{~d}} / \mathrm{I}_{\mathrm{Ce3d}}\right)$ is 0.0056 for $\mathrm{Ru} / \mathrm{CeO}_{2}-\mathrm{H}$, which is lower than that of the corresponding sample without heat treatment $(0.0075)$. The suboxides would hinder the reduction of $\mathrm{Ru}$ oxide, thus a high proportion of $\mathrm{Ru}$ species in the form of ruthenium oxide still exists after hydrogen reduction. On the other hand, the oxygen vacancies and partially reduced ceria can provide electrons to $\mathrm{Ru}$ metal, ${ }^{8,} 45$ leading to the formation of electron-enriched $\mathrm{Ru}$ species $\left(\mathrm{Ru}^{\mathrm{\delta}-}\right)$, in line with the observation over Au catalyst. ${ }^{45}$ In such a case, the presence of a larger amount of $\mathrm{Ce}^{3+}$ and oxygen vacancy over the $\mathrm{Ru} / \mathrm{CeO}_{2}-\mathrm{C} 250 \mathrm{H}$ and $\mathrm{Ru} / \mathrm{CeO}_{2}-\mathrm{C} 500 \mathrm{H}$ samples would result in increase of $\mathrm{Ru}^{\delta-}$, causing a shift of $\mathrm{Ru} 3 \mathrm{~d}_{5 / 2}$ peak to lower binding energy. The dissociation of $\mathrm{CO}$ on $\mathrm{Ru}$ surface and the spillover of oxygen that follows would hinder $\mathrm{Ru}$ species from being covered by ceria, ${ }^{31}$ and the presence of $\mathrm{Ru}$ metal causes the reduction of ceria preferentially following the hydrogen spillover mechanism during the subsequent hydrogen treatment of the CO-activated samples (Figure S8). Then the $\left(\mathrm{Ru}^{0}+\mathrm{Ru}^{\delta-}\right) /\left(\mathrm{Ru}^{0}+\mathrm{Ru}^{\delta-}+\mathrm{Ru}^{\mathrm{n}+}\right)$ ratio increases up to $71.6 \%$ and $60.6 \%$ for $\mathrm{Ru} / \mathrm{CeO}_{2}-\mathrm{C} 250 \mathrm{H}$ and $\mathrm{Ru} / \mathrm{CeO}_{2}-\mathrm{C} 500 \mathrm{H}$, respectively, and the $\mathrm{I}_{\mathrm{Ru} 3 \mathrm{~d}} / \mathrm{I}_{\mathrm{Ce} 3 \mathrm{~d}}$ ratio also increases for $\mathrm{Ru} / \mathrm{CeO}_{2}-\mathrm{C} 250 \mathrm{H}(0.01)$ and $\mathrm{Ru} / \mathrm{CeO}_{2}-\mathrm{C} 500 \mathrm{H}(0.0095)$.

Raman experiment was conducted to study the defects of samples, and the results are shown in Figure 2. Four peaks can be found in the Raman spectrum of $\mathrm{CeO}_{2}$ : a strong peak at $460 \mathrm{~cm}^{-1}$ (fluorite $\mathrm{F} 2 \mathrm{~g}$ mode) and three weak peaks at 250, 587 and $1180 \mathrm{~cm}^{-1}$, corresponding to second-order transverse acoustic mode (2TA), defectinduced mode (D), and second-order longitudinal optical mode (2LO), respectively. ${ }^{28,} 35,41,46-48$ The Raman peaks at $250 \mathrm{~cm}^{-1}$ and $460 \mathrm{~cm}^{-1}$ shift to lower wavenumber after the introduction of Ru species into ceria for $\mathrm{Ru} / \mathrm{CeO}_{2}-\mathrm{H}$, suggesting that there is electron transfer from $\mathrm{Ru}$ species to $\mathrm{CeO}_{2}$ for the hydrogen reduced $\mathrm{Ru} / \mathrm{CeO}_{2} \cdot{ }^{49}$ The $\mathrm{I}_{(587+1180)} / \mathrm{I}_{460}$ ratio that reflects defect concentration such as oxygen vacancies, ${ }^{41,} 46,50-51$ was calculated by means of peak fitting. It is obvious that the presence of $\mathrm{Ru}$ species results in an increase of ceria defects, in agreement with previous results. ${ }^{10,35}$ The two peaks at $695 \mathrm{~cm}^{-1}$ and $970 \mathrm{~cm}^{-1}$ are assignable to the $\mathrm{Ru}^{\delta-}-\mathrm{O}_{\mathrm{V}}-\mathrm{Ce}^{3+}$ bond of $\mathrm{Ru} / \mathrm{CeO}_{2}-\mathrm{H}$ arising from metal-support interaction. ${ }^{28,35,51}$ The number of ceria defects and $\mathrm{Ru}^{\mathrm{\delta}-}-\mathrm{O}_{\mathrm{V}^{-}}-\mathrm{Ce}^{3+}$ bonds significantly increase for $\mathrm{Ru} / \mathrm{CeO}_{2}-\mathrm{C} 250 \mathrm{H}$ and $\mathrm{Ru} / \mathrm{CeO}_{2}-\mathrm{C} 500 \mathrm{H}$. It is especially so in the case of $\mathrm{CO}$ activation at $500{ }^{\circ} \mathrm{C}$. Among the three prepared catalysts, $\mathrm{Ru} / \mathrm{CeO}_{2}-\mathrm{C} 500 \mathrm{H}$ is the highest in the amount of ceria defects and $\mathrm{Ru}^{\delta-}-\mathrm{O}_{\mathrm{V}}-\mathrm{Ce}^{3+}$ bonds. Referring to pure ceria, the peak of fluorite $\mathrm{F} 2 \mathrm{~g}$ mode remains unchanged in the $\mathrm{Ru} / \mathrm{CeO}_{2}-\mathrm{C} 250 \mathrm{H}$ and $\mathrm{Ru} / \mathrm{CeO}_{2}-\mathrm{C} 500 \mathrm{H}$ cases, indicating that the transfer of electron from $\mathrm{Ru}$ species to $\mathrm{CeO}_{2}$ is inhibited, which is consistent with the XPS result that electron transfer is from ceria to Ru species. 
Figure 2 (Left) Raman spectra of various samples and (Right) $\mathrm{I}_{695+970} / \mathrm{I}_{460}$ and $\mathrm{I}_{587+1180} / \mathrm{I}_{460}$ intensity ratios.

Overall, combining the DRIFTS, XPS and Raman results, it can be deduced that the reducibility and exposure of $\mathrm{Ru}$ species would significantly increase after $\mathrm{CO}$ activation of $\mathrm{Ru} / \mathrm{CeO}_{2}$ catalyst, resulting in significant enhancement of $\mathrm{Ce}^{3+}$, oxygen vacancy and $\mathrm{Ru}^{\delta-}-\mathrm{O}_{\mathrm{V}}-\mathrm{Ce}^{3+}$ concentrations.

\subsection{Ammonia synthesis performance}

Figure 3 reveals the temperature dependence of ammonia synthesis rate and the reaction orders over the prepared catalysts. The increase of reaction temperature leads to enhancement of catalytic activities for all samples, and the $\mathrm{Ru} / \mathrm{CeO}_{2}$ catalysts subjected to $\mathrm{CO}$ activation show higher ammonia synthesis rates than that subjected to hydrogen reduction only. The rates of $\mathrm{Ru} / \mathrm{CeO}_{2}-\mathrm{C} 250 \mathrm{H}$ and $\mathrm{Ru} / \mathrm{CeO}_{2}-\mathrm{C} 500 \mathrm{H}$ are 8.03 mmol g cat ${ }^{-1} \mathrm{~h}^{-1}$ and $9.24 \mathrm{mmol} \mathrm{g} \mathrm{cat}^{-1} \mathrm{~h}^{-1}$ at $400{ }^{\circ} \mathrm{C}$ and $1.0 \mathrm{MPa}$, which are roughly two-fold that of $\mathrm{Ru} / \mathrm{CeO}_{2^{-}}$ $\mathrm{H}\left(4.06 \mathrm{mmol} \mathrm{g} \mathrm{gat}^{-1} \mathrm{~h}^{-1}\right)$ under the same reaction conditions. The turnover frequencies for Ru catalysts with $\mathrm{CO}$ activation are comparable to those of $\mathrm{Ru}$ catalysts reported in literatures (Table S2). ${ }^{7,}$, $52-57$ As shown in Figure $\mathrm{S} 9, \mathrm{Ru} / \mathrm{CeO}_{2}-\mathrm{C} 250 \mathrm{H}$ and $\mathrm{Ru} / \mathrm{CeO}_{2}-\mathrm{C} 500 \mathrm{H}$ show stability better than that of $\mathrm{Ru} / \mathrm{CeO}_{2}-\mathrm{H}$. The estimated activation energies are 60,67 and $72 \mathrm{~kJ} \mathrm{~mol}^{-1}$ for $\mathrm{Ru} / \mathrm{CeO}_{2}-\mathrm{H}, \mathrm{Ru} / \mathrm{CeO}_{2}-\mathrm{C} 250 \mathrm{H}$ and $\mathrm{Ru} / \mathrm{CeO}_{2}$ $\mathrm{C} 500 \mathrm{H}$, respectively, suggesting that the significant discrepancy in ammonia synthesis activity among the three cannot be directly attributed to the change of activation energy. The reaction orders of $\mathrm{N}_{2}$ are 1.0, 1.2 and 1.3 for $\mathrm{Ru} / \mathrm{CeO}_{2}-\mathrm{H}, \mathrm{Ru} / \mathrm{CeO}_{2}-\mathrm{C} 250 \mathrm{H}$ and $\mathrm{Ru} / \mathrm{CeO}_{2}-\mathrm{C} 500 \mathrm{H}$, respectively, and the corresponding reaction orders of $\mathrm{NH}_{3}$ are $-0.72,-0.75$ and -0.79 . On the other hand, the estimated $\mathrm{H}_{2}$ reaction order is negative (-0.53) for $\mathrm{Ru} / \mathrm{CeO}_{2}-\mathrm{H}$, but changes to 0.3 and 0.36 for $\mathrm{Ru} / \mathrm{CeO}_{2}-\mathrm{C} 250 \mathrm{H}$ and $\mathrm{Ru} / \mathrm{CeO}_{2}-\mathrm{C} 500 \mathrm{H}$, respectively, suggesting that $\mathrm{CO}$ activation can alleviate the problem of hydrogen poisoning for $\mathrm{Ru}$ catalysts. Hence the increase of reaction pressure form 1 to $7 \mathrm{MPa}$ leads to a more significant enhancement of the activity for the CO-activated $\mathrm{Ru}$ catalysts $\left(\mathrm{Ru} / \mathrm{CeO}_{2}-\mathrm{C} 250 \mathrm{H}\right.$ and $\left.\mathrm{Ru} / \mathrm{CeO}_{2}-\mathrm{C} 500 \mathrm{H}\right)$ in comparison with the $\mathrm{Ru} / \mathrm{CeO}_{2}-\mathrm{H}$ catalyst (Figure S10). It can also be deduced that $\mathrm{CO}$ activation mainly affects the performance of $\mathrm{Ru} / \mathrm{CeO}_{2}$ catalysts by changing the hydrogen adsorption/desorption property.

Figure 3 (a) Temperature dependence of ammonia synthesis rate $\left(0.2 \mathrm{~g}, 1.0 \mathrm{MPa}, 120 \mathrm{~mL} \mathrm{~min}{ }^{-1}\right)$ and (b) $\mathrm{N}_{2}, \mathrm{H}_{2}$ and $\mathrm{NH}_{3}$ reaction orders.

\subsection{Adsorption property of Ru catalysts}

To better understand why $\mathrm{CO}$ activation enhances the performance of $\mathrm{Ru} / \mathrm{CeO}_{2}$ catalysts, various characterization techniques were employed to investigate the activation of the catalysts as well as the adsorption and desorption of reactants. $\mathrm{H}_{2}$ molecules can dissociate on $\mathrm{Ru}^{0}$ metallic sites to form hydrides, and then the $\mathrm{H}$ atoms can spillover to the support to generate hydroxyl groups. ${ }^{58-60}$ Molecular $\mathrm{H}_{2}$ also dissociate on ceria to form heterolytic products (Ce-H and $\mathrm{OH}$ ) and homolytic products (two $\mathrm{OH}$ groups) ${ }^{61-62}$ The presence of $\mathrm{Ru}$ species facilitates the desorption of hydrogen species at a raised temperature either in the form of water or hydrogen molecule (Figure S11). A D/H exchange reaction was designed to explore the adsorption nature of hydrogen on the Ru catalysts. After $\mathrm{D}_{2}$ adsorption at $400 \mathrm{degC}$ and $\mathrm{Ar}$ purging at $50 \mathrm{degC}$ for $60 \mathrm{~min}$, a $3.3 \% \mathrm{~N}_{2}-10 \% \mathrm{H}_{2}$-Ar mixture was introduced to the catalysts (Figure 4). Although a large amount of hydrogen species would adsorb on ceria (Figure S11), there is little production of D-containing species during D/H exchange reaction at $50 \mathrm{deg} \mathrm{C}$, which might be due to the strong adsorption of $\mathrm{D}$ species. Compared to $\mathrm{CeO}_{2}$, the production of $\mathrm{HD}, \mathrm{D}_{2}, \mathrm{HDO}$ and $\mathrm{D}_{2} \mathrm{O}$ is significantly higher over the Ru catalysts, confirming that the presence of $\mathrm{Ru}$ species facilitates desorption of $\mathrm{D}$ species. Because the concentrations of HD and HDO are much larger than those of $\mathrm{D}_{2}$ and $\mathrm{D}_{2} \mathrm{O}$, it can be concluded that there is dynamic exchange of deuterium species adsorbed on $\mathrm{Ru}$ and the hydrogen species from gaseous phase. Furthermore, the signals of HDO and $\mathrm{D}_{2} \mathrm{O}$ evolution over $\mathrm{Ru} / \mathrm{CeO}_{2}-\mathrm{C} 500 \mathrm{H}$ are stronger than those over $\mathrm{Ru} / \mathrm{CeO}_{2}-\mathrm{H}$, revealing that there is a larger amount of $\mathrm{D}$ species on the former that would desorb from Ru sites by reacting with neighboring oxygen atoms. The presence of active oxygen on the Ru catalysts is confirmed by CO-TPR analysis; and the amount of active oxygen on the $\mathrm{CO}$ activated catalysts are higher than that on the hydrogen-treated one (Figure S12). Moreover, two $\mathrm{CO}_{2}$ evolution peaks at $190 \operatorname{degC}$ and $363 \operatorname{deg} \mathrm{C}$ can be found over the 
$\mathrm{CO}$ activated $\mathrm{Ru}$ catalysts, proving that there are surface lattice oxygen species which would much more easily react with $\mathrm{CO} .{ }^{63-64}$ The $\mathrm{CO}_{2}$ evolution peaks at $190 \operatorname{deg} \mathrm{C}$ and $363 \mathrm{deg} \mathrm{C}$ are absent in the case of $\mathrm{Ru} / \mathrm{CeO}_{2}-\mathrm{H}$. The discrepancy in the property of surface lattice oxygen might be attributed to the pathways of oxygen spillover during the thermal treatment process as a result of using different agents for the reduction of the $\mathrm{Ru}$ catalysts (Figure S8).

Figure 4 Evolution profiles of $\mathrm{HD}, \mathrm{D}_{2}, \mathrm{HDO}$, and $\mathrm{D}_{2} \mathrm{O}$ with time at 50 degC detected by mass spectrometry during the $\mathrm{D} / \mathrm{H}$ exchange reaction.

In comparison with the $\mathrm{Ru} / \mathrm{CeO}_{2}-\mathrm{H}$ and $\mathrm{Ru} / \mathrm{CeO}_{2}-\mathrm{C} 500 \mathrm{H}$ catalysts, much stronger $\mathrm{HD}, \mathrm{D}_{2}, \mathrm{HDO}$ and $\mathrm{D}_{2} \mathrm{O}$ signals are observed over ceria with the rise of temperature during TPSR study in $3.3 \% \mathrm{~N}_{2}-10 \% \mathrm{H}_{2}-\mathrm{Ar}$ mixture over the samples pre-adsorbed with $\mathrm{D}_{2}$ (Figure S13), further confirming that the presence of $\mathrm{Ru}$ species facilitates the desorption of deuterium species. Despite significantly weaker, there are $\mathrm{HD}$ and $\mathrm{D}_{2}$ desorption over the ceria-supported Ru catalysts below 300 degC, suggesting that most of the deuterium species adsorbed on ceria could be removed during TPSR study. It can be concluded that the hydrogen species from the gaseous phase is responsible for ammonia synthesis, which is in line with the observation of Kammert et al. over $\mathrm{Ru} / \mathrm{C} 12 \mathrm{~A} 7$ electride catalyst. It was report that hydrogen species adsorbed on $\mathrm{Ru}$ species, rather than the hydride encaged in the C12A7 electride contributed to ammonia synthesis. ${ }^{65}$ Despite most of the deuterium species pre-adsorbed on $\mathrm{Ru}$ or ceria in the $\mathrm{Ru}$ catalysts has been removed, a series of reaction steps, such as the dissociative adsorption of $\mathrm{H}_{2}$ and $\mathrm{N}_{2}$, the reaction of hydrogen atoms and nitrogen atoms, the formation of water and desorption of $\mathrm{NH}_{\mathrm{x}}$ intermediate species, would continue on the active sites of $\mathrm{Ru}$ catalysts. As a result, the difference in the nature of active sites would exert a strong influence on the reaction pathways of ammonia synthesis.

A possible mechanism for ammonia synthesis over the ceria-supported $\mathrm{Ru}$ catalysts is proposed in Figure 5. There is EMSI between Ru metal and ceria, and $\mathrm{CO}$ activation leads to significant enhancement of $\mathrm{Ru}$ species exposure, $\mathrm{Ce}^{3+}$ concentration, and number of oxygen vacancy. The oxygen vacancies and partially reduced ceria would provide electrons to $\mathrm{Ru}$ metal, leading to the generation of electron-enriched $\mathrm{Ru}^{\delta-}$ species and $\mathrm{Ru}^{\delta-}-\mathrm{O}_{\mathrm{V}}-\mathrm{Ce}^{3+}$ sites. There is electron donation from $\mathrm{Ru}^{\delta-}$ to the antibonding orbital of adsorbed $\mathrm{N}_{2}$, resulting in weakening of $\mathrm{N}[?] \mathrm{N}$ bond. ${ }^{56}$ The $\mathrm{H}_{2}$ molecules can dissociate on $\mathrm{Ru}$ metal sites to form hydrides, and some of the $\mathrm{H}$ atoms migrate to the ceria support and are stabilized by oxygen species. However, too much hydrogen species would hinder nitrogen dissociation and hence the reactions of ammonia synthesis; thus the pre-adsorption of $\mathrm{D}_{2}$ leads to notable decrease of $\mathrm{NH}_{\mathrm{x}}$ mass signals $(\mathrm{m} / \mathrm{z}=15,16$ and 17$)$ over $\mathrm{Ru} / \mathrm{CeO}_{2}-\mathrm{C} 500 \mathrm{H}$ (Figure S14). Nonetheless, with $\mathrm{CO}$ activation, there is ample active oxygen in the $\mathrm{Ru}$ catalysts to remove the surplus hydrogen species on Ru sites, releasing the active sites for $\mathrm{N}_{2}$ dissociation and ammonia synthesis. An overall outcome is the alleviation of hydrogen poisoning effect. $\mathrm{Wu}$ et al. reported that the increase of hydrogen species mobility using polar $\mathrm{MgO}(111)$ instead of nonpolar $\mathrm{MgO}$ could lead to lessening of hydrogen poisoning for $\mathrm{Ru} / \mathrm{MgO}$ catalyst. ${ }^{66}$ Meantime, there are stronger $\mathrm{NH}$ and $\mathrm{NH}_{2}$ signals over $\mathrm{Ru} / \mathrm{CeO}_{2}-\mathrm{C} 500 \mathrm{H}$ as compared to those over $\mathrm{Ru} / \mathrm{CeO}_{2}-\mathrm{H}$ during TPSR study (Figure $\mathrm{S} 15)$. There is water evolution during TPSR study for all Ru catalysts, indicating that the hydrogen species located on surface oxygen participate not only in ammonia formation by reverse spillover, but also in water generation/desoprtion that leads to replenishment of oxygen vacancies. On the other hand, it is envisioned that the spillover effects would be weakened for $\mathrm{Ru} / \mathrm{CeO}_{2}$ catalyst with large $\mathrm{Ru}$ particles, and the result shows that the positive effect of $\mathrm{CO}$ activation on ammonia synthesis decreases with the increase of $\mathrm{Ru}$ loading (Figure S16).

Figure 5 Possible ammonia synthesis pathways over a ceria-supported Ru catalyst. (a) Electron transfer from partially reduced ceria and oxygen vacancies to Ru metal on ceria surface, (b) N[?]N bond weakening as a result of electron donation from the electron-enriched $\mathrm{Ru}^{\delta-}$ species to the antibonding orbital of $\mathrm{N}_{2}$, together with $\mathrm{H}_{2}$ dissociative adsorption on $\mathrm{Ru}$ surface, and $\mathrm{H}$ atom migration and stabilization by oxygen species. (c) $\mathrm{N}$ atoms on $\mathrm{Ru}$ surface react with the neighboring $\mathrm{H}$ atoms for form ammonia. Also, $\mathrm{H}$ atoms in ceria desorb via water generation.

\section{Conclusions}


We have successfully prepared ceria-supported Ru catalysts with high degree of reduction and high exposure of $\mathrm{Ru}$ species by $\mathrm{CO}$ activation. The $\mathrm{CO}$ treatment also leads to significant increase of $\mathrm{Ce}^{3+}$, oxygen vacancy and active oxygen concentration. A combination of DRIFTS, XPS and Raman investigations reveals that the evolution of partially reduced ceria and oxygen vacancies would lead to the formation of electronenriched $\mathrm{Ru}^{\delta-}$ species and $\mathrm{Ru}^{\delta-}-\mathrm{O}_{\mathrm{V}}-\mathrm{Ce}^{3+}$ sites, which would facilitate the dissociation of dinitrogen. The $\mathrm{D} / \mathrm{H}$ exchange and TPSR experiments show that there is dynamic exchange of hydrogen species adsorbed on $\mathrm{Ru}$ catalysts with that from the gaseous phase. The presence of a larger amount of active oxygen on the $\mathrm{CO}$ activated $\mathrm{Ru}$ catalysts can help remove the surplus hydrogen species on the $\mathrm{Ru}$ sites, releasing the active sites for $\mathrm{N}_{2}$ adsorption/dissociation and ammonia synthesis. As a result, $\mathrm{CO}$ activation of $\mathrm{Ru} / \mathrm{CeO}_{2}$ catalyst significantly enhances the ammonia synthesis activity, showing roughly a two-fold increase, and the ill effect of hydrogen poisoning for Ru catalysts is alleviated. These findings are important for the design of supported metal catalysts for reactions that are based on metallic active sites.

\section{Supporting Information}

The calculation results of mass transport and heat transfer, reaction orders, temperature dependence of ammonia synthesis rates, Arrhenius plots, time dependence of ammonia synthesis rates, HAADF-STEM image and the corresponding element mappings, TEM images, DRIFTS spectra, XPS Ce3d spectra, O1s spectra, mass signals obtained from $\mathrm{H}_{2}$-TPD measurement, Time-resolved D/H exchange reaction and TPSR, $\mathrm{D}_{2}$-TPD of ceria, textural property of samples, Catalytic performance of various $\mathrm{Ru}$ catalysts reported elsewhere and related references.

\section{Acknowledgments}

This work was financially supported by the National Science Foundation of China (Nos. 21776047, 21825801, 21978051) and the Program for Qishan Scholar of Fuzhou University (Grant XRC-18033).

\section{References}

1. Smil, V., Detonator of the population explosion. Nature1999, 400, 415-415.

2. Guo, C.; Ran, J.; Vasileff, A.; Qiao, S.-Z., Rational design of electrocatalysts and photo(electro)catalysts for nitrogen reduction to ammonia $\left(\mathrm{NH}_{3}\right)$ under ambient conditions. Energy Environ. Sci. 2018, 11, 45-56.

3. Guo, J.; Chen, P., Catalyst: $\mathrm{NH}_{3}$ as an Energy Carrier. Chem 2017, 3, 709-712.

4. Patil, B. S.; Wang, Q.; Hessel, V.; Lang, J., Plasma $\mathrm{N}_{2}$-fixation: 1900-2014. Catal. Today2015, 256, $49-66$.

5. Baltrusaitis, J., Sustainable Ammonia Production. ACS Sustainable Chem. Eng. 2017, 5, 9527-9527.

6. Demirhan, C. D.; Tso, W. W.; Powell, J. B.; Pistikopoulos, E. N., Sustainable ammonia production through process synthesis and global optimization. AIChE J. 2019, 65.

7. Ma, Z.; Zhao, S.; Pei, X.; Xiong, X.; Hu, B., New insights into the support morphology-dependent ammonia synthesis activity of $\mathrm{Ru} / \mathrm{CeO}_{2}$ catalysts. Catal. Sci. Technol.2017, 7, 191-199.

8. Niwa, Y.; Aika, K.-i., The Effect of Lanthanide Oxides as a Support for Ruthenium Catalysts in Ammonia Synthesis. J. Catal.1996, 162, 138-142.

9. Ogura, Y.; Sato, K.; Miyahara, S.-i.; Kawano, Y.; Toriyama, T.; Yamamoto, T.; Matsumura, S.; Hosokawa, S.; Nagaoka, K., Efficient ammonia synthesis over a $\mathrm{Ru} / \mathrm{La}_{0.5} \mathrm{Ce}_{0.5} \mathrm{O}_{1.75}$ catalyst pre-reduced at high temperature. Chem. Sci.2018, 9, 2230-2237.

10. Lin, B.; Liu, Y.; Heng, L.; Wang, X.; Ni, J.; Lin, J.; Jiang, L., Morphology Effect of Ceria on the Catalytic Performances of $\mathrm{Ru} / \mathrm{CeO}_{2}$ Catalysts for Ammonia Synthesis. Ind. Eng. Chem. Res. 2018, 57, 9127-9135. 
11. Wu, Y.; Li, C.; Fang, B.; Wang, X.; Ni, J.; Lin, B.; Lin, J.; Jiang, L., Enhanced ammonia synthesis performance of ceria-supported $\mathrm{Ru}$ catalysts via introduction of titanium. Chem. Commun.2020, 56, 11411144 .

12. Campbell, C. T., Electronic perturbations. Nat. Chem.2012, 4, 597-598.

13. van Deelen, T. W.; Hernández Mejía, C.; de Jong, K. P., Control of metal-support interactions in heterogeneous catalysts to enhance activity and selectivity. Nat. Catal. 2019, 2, 955-970.

14. Lykhach, Y.; Kozlov, S. M.; Skála, T.; Tovt, A.; Stetsovych, V.; Tsud, N.; Dvořák, F.; Johánek, V.; Neitzel, A.; Mysliveček, J.; Fabris, S.; Matolín, V.; Neyman, K. M.; Libuda, J., Counting electrons on supported nanoparticles. Nat. Mater, 2016, 15, 284-288.

15. An, J.; Wang, Y.; Lu, J.; Zhang, J.; Zhang, Z.; Xu, S.; Liu, X.; Zhang, T.; Gocyla, M.; Heggen, M.; Dunin-Borkowski, R. E.; Fornasiero, P.; Wang, F., Acid-Promoter-Free Ethylene Methoxycarbonylation over Ru-Clusters/Ceria: The Catalysis of Interfacial Lewis Acid-Base Pair.J. Am. Chem. Soc. 2018, 140, 41724181.

16. Zhang, Z.; Wang, Y.; Lu, J.; Zhang, J.; Li, M.; Liu, X.; Wang, F., Pr-Doped $\mathrm{CeO}_{2}$ Catalyst in the Prins Condensation-Hydrolysis Reaction: Are All of the Defect Sites Catalytically Active? ACS Catal. 2018, 8, $2635-2644$.

17. Matsubu, J. C.; Zhang, S.; DeRita, L.; Marinkovic, N. S.; Chen, J. G.; Graham, G. W.; Pan, X.; Christopher, P., Adsorbate-mediated strong metal-support interactions in oxide-supported Rh catalysts. Nat. Chem. 2017, 9, 120-127.

18. Tang, H.; Su, Y.; Zhang, B.; Lee, A. F.; Isaacs, M. A.; Wilson, K.; Li, L.; Ren, Y.; Huang, J.; Haruta, M.; Qiao, B.; Liu, X.; Jin, C.; Su, D.; Wang, J.; Zhang, T., Classical strong metal-support interactions between gold nanoparticles and titanium dioxide. Sci. Adv.2017, 3, e1700231.

19. Zhang, J.; Wang, H.; Wang, L.; Ali, S.; Wang, C.; Wang, L.; Meng, X.; Li, B.; Su, D. S.; Xiao, F.-S., WetChemistry Strong Metal-Support Interactions in Titania-Supported Au Catalysts. J. Am. Chem. Soc.2019, 141, 2975-2983.

20. Bruix, A.; Rodriguez, J. A.; Ramírez, P. J.; Senanayake, S. D.; Evans, J.; Park, J. B.; Stacchiola, D.; Liu, P.; Hrbek, J.; Illas, F., A New Type of Strong Metal-Support Interaction and the Production of $\mathrm{H}_{2}$ through the Transformation of Water on $\mathrm{Pt} / \mathrm{CeO}_{2}(111)$ and $\mathrm{Pt} / \mathrm{CeO}_{\mathrm{x}} / \mathrm{TiO}_{2}(110)$ Catalysts. J. Am. Chem. Soc. 2012, 134, 8968-8974.

21. Pacchioni, G.; Freund, H.-J., Controlling the charge state of supported nanoparticles in catalysis: lessons from model systems. Chem. Soc. Rev. 2018, 47, 8474-8502.

22. Zhang, B.; Qin, Y., Interface Tailoring of Heterogeneous Catalysts by Atomic Layer Deposition. ACS Catal. 2018, 8, 10064-10081.

23. Wei, X.; Shao, B.; Zhou, Y.; Li, Y.; Jin, C.; Liu, J.; Shen, W., Geometrical Structure of the Gold-Iron(III) Oxide Interfacial Perimeter for CO Oxidation. Angew. Chem. Int. Ed. 2018, 57, 11289-11293.

24. Chen, A.; Yu, X.; Zhou, Y.; Miao, S.; Li, Y.; Kuld, S.; Sehested, J.; Liu, J.; Aoki, T.; Hong, S.; Camellone, M. F.; Fabris, S.; Ning, J.; Jin, C.; Yang, C.; Nefedov, A.; Wöll, C.; Wang, Y.; Shen, W., Structure of the catalytically active copper-ceria interfacial perimeter.Nat. Catal. 2019, 2, 334-341.

25. Xie, C.; Niu, Z.; Kim, D.; Li, M.; Yang, P., Surface and Interface Control in Nanoparticle Catalysis. Chem. Rev. 2020, 120, 1184-1249.

26. Liu, Z.-P.; Hu, P.; Lee, M.-H., Insight into association reactions on metal surfaces: Density-functional theory studies of hydrogenation reactions on $\mathrm{Rh}(111)$. J. Chem. Phys. 2003, 119, 6282-6289. 
27. Ertl, G., Reactions at Surfaces: From Atoms to Complexity (Nobel Lecture). Angew. Chem. Int. Ed. 2008, 47, 3524-3535.

28. Guo, Y.; Mei, S.; Yuan, K.; Wang, D.-J.; Liu, H.-C.; Yan, C.-H.; Zhang, Y.-W., Low-Temperature $\mathrm{CO}_{2}$ Methanation over $\mathrm{CeO}_{2}$-Supported Ru Single Atoms, Nanoclusters, and Nanoparticles Competitively Tuned by Strong Metal-Support Interactions and H-Spillover Effect. ACS Catal. 2018, 8, 6203-6215.

29. Gänzler, A.; Casapu, M.; Maurer, F.; Störmer, H.; Gerthsen, D.; Ferré, G.; Vernoux, P.; Bornmann, B.; Frahm, R.; Murzin, V.; Nachtegaal, M.; Votsmeier, M.; Grunwaldt, J.-D., Tuning the Pt/CeO ${ }_{2}$-Interface by In Situ Variation of the Pt Particle Size. ACS Catal. 2018, 8, 4800-4811.

30. Han, B.; Guo, Y.; Huang, Y.; Xi, W.; Xu, J.; Luo, J.; Qi, H.; Ren, Y.; Liu, X.; Qiao, B.; Zhang, T., Strong Metal-Support Interactions between Pt Single Atoms and $\mathrm{TiO}_{2}$. Angew. Chem. Int. Ed. 2020, 59, 11824-11829.

31. Parastaev, A.; Muravev, V.; Huertas Osta, E.; van Hoof, A. J. F.; Kimpel, T. F.; Kosinov, N.; Hensen, E. J. M., Boosting $\mathrm{CO}_{2}$ hydrogenation via size-dependent metal-support interactions in cobalt/ceria-based catalysts. Nat. Catal.2020, 3, 526-533.

32. Mai, H.-X.; Sun, L.-D.; Zhang, Y.-W.; Si, R.; Feng, W.; Zhang, H.-P.; Liu, H.-C.; Yan, C.-H., ShapeSelective Synthesis and Oxygen Storage Behavior of Ceria Nanopolyhedra, Nanorods, and Nanocubes.J. Phys. Chem. B 2005, 109, 24380-24385.

33. Oyama, S. T.; Zhang, X.; Lu, J.; Gu, Y.; Fujitani, T., Epoxidation of propylene with $\mathrm{H}_{2}$ and $\mathrm{O}_{2}$ in the explosive regime in a packed-bed catalytic membrane reactor. J. Catal. 2008, 257, 1-4.

34. Mears, D. E., Tests for Transport Limitations in Experimental Catalytic Reactors. Ind. Eng. Chem. Process Des. Dev.1971, 10, 541-547.

35. Huang, H.; Dai, Q.; Wang, X., Morphology effect of $\mathrm{Ru} / \mathrm{CeO}_{2}$ catalysts for the catalytic combustion of chlorobenzene. Appl. Catal. B 2014, 158-159, 96-105.

36. NIST X-ray Photoelectron Spectroscopy Database, NIST Standard Reference Database 20. Version 4.1 (Web Version).

37. Lin, B.; Heng, L.; Fang, B.; Yin, H.; Ni, J.; Wang, X.; Lin, J.; Jiang, L., Ammonia Synthesis Activity of Alumina-Supported Ruthenium Catalyst Enhanced by Alumina Phase Transformation. ACS Catal.2019, 9, $1635-1644$.

38. Lin, B.; Heng, L.; Yin, H.; Fang, B.; Ni, J.; Wang, X.; Lin, J.; Jiang, L., Effects of Using Carbon-Coated Alumina as Support for Ba-Promoted Ru Catalyst in Ammonia Synthesis. Ind. Eng. Chem. Res. 2019, 58, 10285-10295.

39. Chin, S. Y.; Williams, C. T.; Amiridis, M. D., FTIR Studies of CO Adsorption on $\mathrm{Al}_{2} \mathrm{O}_{3^{-}}$and $\mathrm{SiO}_{2^{-}}$ Supported Ru Catalysts. J. Phys. Chem. B2006, 110, 871-882.

40. Panagiotopoulou, P.; Kondarides, D. I.; Verykios, X. E., Mechanistic Study of the Selective Methanation of $\mathrm{CO}$ over $\mathrm{Ru} / \mathrm{TiO}_{2}$ Catalyst: Identification of Active Surface Species and Reaction Pathways. J. Phys. Chem. C 2011, 115, 1220-1230.

41. Hu, Z.; Liu, X.; Meng, D.; Guo, Y.; Guo, Y.; Lu, G., Effect of Ceria Crystal Plane on the Physicochemical and Catalytic Properties of Pd/Ceria for CO and Propane Oxidation. ACS Catal. 2016,6, 2265-2279.

42. Gänzler, A. M.; Casapu, M.; Vernoux, P.; Loridant, S.; Cadete Santos Aires, F. J.; Epicier, T.; Betz, B.; Hoyer, R.; Grunwaldt, J.-D., Tuning the Structure of Platinum Particles on Ceria In Situ for Enhancing the Catalytic Performance of Exhaust Gas Catalysts.Angew. Chem. Int. Ed. 2017, 56, 13078-13082.

43. Vayssilov, G. N.; Lykhach, Y.; Migani, A.; Staudt, T.; Petrova, G. P.; Tsud, N.; Skala, T.; Bruix, A.; Illas, F.; Prince, K. C.; Matolı́n, V. r.; Neyman, K. M.; Libuda, J., Support nanostructure boosts oxygen 
transfer to catalytically active platinum nanoparticles. Nat. Mater, 2011, 10, 310-315.

44. Ro, I.; Resasco, J.; Christopher, P., Approaches for Understanding and Controlling Interfacial Effects in Oxide-Supported Metal Catalysts. ACS Catal. 2018, 8, 7368-7387.

45. Liu, N.; Xu, M.; Yang, Y.; Zhang, S.; Zhang, J.; Wang, W.; Zheng, L.; Hong, S.; Wei, M., Au ${ }^{\delta-}-\mathrm{O}_{\mathrm{v}}{ }^{-}$ $\mathrm{Ti}^{3+}$ Interfacial Site: Catalytic Active Center toward Low-Temperature Water Gas Shift Reaction. ACS Catal. 2019, 9, 2707-2717.

46. Tan, H.; Wang, J.; Yu, S.; Zhou, K., Support Morphology-Dependent Catalytic Activity of Pd/CeO 2 for Formaldehyde Oxidation. Environ. Sci. Technol. 2015, 49, 8675-8682.

47. Wu, Z.; Li, M.; Howe, J.; Meyer, H. M.; Overbury, S. H., Probing Defect Sites on CeO 2 Nanocrystals with Well-Defined Surface Planes by Raman Spectroscopy and O2 Adsorption. Langmuir 2010, 26, 16595-16606.

48. Wu, Z.; Li, M.; Overbury, S. H., On the structure dependence of CO oxidation over $\mathrm{CeO}_{2}$ nanocrystals with well-defined surface planes. J. Catal. 2012, 285, 61-73.

49. Rao, A. M.; Eklund, P. C.; Bandow, S.; Thess, A.; Smalley, R. E., Evidence for charge transfer in doped carbon nanotube bundles from Raman scattering. Nature 1997, 388, 257-259.

50. Huang, H.; Dai, Q.; Wang, X., Morphology effect of Ru/CeO2 catalysts for the catalytic combustion of chlorobenzene. Appl. Catal. B2014, 158-159, 96-105.

51. Wang, F.; Li, C.; Zhang, X.; Wei, M.; Evans, D. G.; Duan, X., Catalytic behavior of supported Ru nanoparticles on the $\{100\},\{110\}$, and $\{111\}$ facet of $\mathrm{CeO}_{2}$. J. Catal.2015, 329, 177-186.

52. Kitano, M.; Inoue, Y.; Sasase, M.; Kishida, K.; Kobayashi, Y.; Nishiyama, K.; Tada, T.; Kawamura, S.; Yokoyama, T.; Hara, M.; Hosono, H., Self-organized Ruthenium-Barium Core-Shell Nanoparticles on a Mesoporous Calcium Amide Matrix for Efficient Low-Temperature Ammonia Synthesis. Angew. Chem. Int. Ed. 2018, 57, 2648-2652.

53. Sato, K.; Imamura, K.; Kawano, Y.; Miyahara, S.-i.; Yamamoto, T.; Matsumura, S.; Nagaoka, K., A low-crystalline ruthenium nano-layer supported on praseodymium oxide as an active catalyst for ammonia synthesis. Chem. Sci. 2017, 8, 674-679.

54. Kobayashi, Y.; Tang, Y.; Kageyama, T.; Yamashita, H.; Masuda, N.; Hosokawa, S.; Kageyama, H., Titanium-Based Hydrides as Heterogeneous Catalysts for Ammonia Synthesis. J. Am. Chem. Soc. 2017,139, 18240-18246.

55. Lu, Y.; Li, J.; Tada, T.; Toda, Y.; Ueda, S.; Yokoyama, T.; Kitano, M.; Hosono, H., Water Durable Electride $\mathrm{Y}_{5} \mathrm{Si}_{3}$ : Electronic Structure and Catalytic Activity for Ammonia Synthesis. J. Am. Chem. Soc.2016, 138, 3970-3973.

56. Kitano, M.; Inoue, Y.; Yamazaki, Y.; Hayashi, F.; Kanbara, S.; Matsuishi, S.; Yokoyama, T.; Kim, S.-W.; Hara, M.; Hosono, H., Ammonia synthesis using a stable electride as an electron donor and reversible hydrogen store. Nat. Chem. 2012, 4, 934-940.

57. Ogura, Y.; Tsujimaru, K.; Sato, K.; Miyahara, S.-i.; Toriyama, T.; Yamamoto, T.; Matsumura, S.; Nagaoka, K., Ru/La ${ }_{0.5} \mathrm{Pr}_{0.5} \mathrm{O}_{1.75}$ Catalyst for Low-Temperature Ammonia Synthesis. ACS Sustainable Chem. Eng. 2018, 6, 17258-17266.

58. Qin, R.; Zhou, L.; Liu, P.; Gong, Y.; Liu, K.; Xu, C.; Zhao, Y.; Gu, L.; Fu, G.; Zheng, N., Alkali ions secure hydrides for catalytic hydrogenation. Nat. Catal. 2020 .

59. J.Halpern, The Catalytic Activation of Hydrogen in Homogeneous, Heterogeneous, and Biological Systems. Adv. Catal. 1959,11, 301-370.

60. Karim, W.; Spreafico, C.; Kleibert, A.; Gobrecht, J.; VandeVondele, J.; Ekinci, Y.; van Bokhoven, J. A., Catalyst support effects on hydrogen spillover. Nature 2017, 541, 68-71. 
61. Wu, Z.; Cheng, Y.; Tao, F.; Daemen, L.; Foo, G. S.; Nguyen, L.; Zhang, X.; Beste, A.; Ramirez-Cuesta, A. J., Direct Neutron Spectroscopy Observation of Cerium Hydride Species on a Cerium Oxide Catalyst.J. Am. Chem. Soc. 2017, 139, 9721-9727.

62. Li, Z.; Werner, K.; Qian, K.; You, R.; Płucienik, A.; Jia, A.; Wu, L.; Zhang, L.; Pan, H.; Kuhlenbeck, H.; Shaikhutdinov, S.; Huang, W.; Freund, H.-J., Oxidation of Reduced Ceria by Incorporation of Hydrogen.Angew. Chem. Int. Ed. 2019, 58, 14686-14693.

63. Zhang, X.-m.; Tian, P.; Tu, W.; Zhang, Z.; Xu, J.; Han, Y.-F., Tuning the Dynamic Interfacial Structure of Copper-Ceria Catalysts by Indium Oxide during CO Oxidation. ACS Catal. 2018, 8, 5261-5275.

64. Zhai, Y.; Pierre, D.; Si, R.; Deng, W.; Ferrin, P.; Nilekar, A. U.; Peng, G.; Herron, J. A.; Bell, D. C.; Saltsburg, H.; Mavrikakis, M.; Flytzani-Stephanopoulos, M., Alkali-Stabilized Pt-OHx Species Catalyze Low-Temperature Water-Gas Shift Reactions. Science 2010,329, 1633-1636.

65. Kammert, J.; Moon, J.; Cheng, Y.; Daemen, L.; Irle, S.; Fung, V.; Liu, J.; Page, K.; Ma, X.; Phaneuf, V.; Tong, J.; Ramirez-Cuesta, A. J.; Wu, Z., Nature of Reactive Hydrogen for Ammonia Synthesis over a Ru/C12A7 Electride Catalyst. J. Am. Chem. Soc. 2020,142, 7655-7667.

66. Wu, S.; Peng, Y.-K.; Chen, T.; Mo, J.; Large, A.; McPherson, I.; Chou, H.-L.; Wilkinson, I.; Venturini, F.; Grinter, D.; Ferrer, P.; Held, G.; Tsang, S. C. E., Removal of Hydrogen Poisoning by Electrostatically Polar MgO Support for Low Pressure $\mathrm{NH}_{3}$ Synthesis at High Rate over Ru Catalyst. ACS Catal.2020, 10, $5614-5622$. 